\title{
Negotiating intergenerational relations and care in diverse African contexts
}

Book or Report Section

Accepted Version

Evans, R. (2015) Negotiating intergenerational relations and care in diverse African contexts. In: Vanderbeck, R. and Worth, N. (eds.) Intergenerational Space. Routledge Studies in Human Geography. Routledge, Abingdon, pp. 199-213. ISBN 9780415855310 Available at http://centaur.reading.ac.uk/37426/

It is advisable to refer to the publisher's version if you intend to cite from the work. See Guidance on citing.

Publisher: Routledge

All outputs in CentAUR are protected by Intellectual Property Rights law, including copyright law. Copyright and IPR is retained by the creators or other copyright holders. Terms and conditions for use of this material are defined in the End User Agreement. 


\section{www.reading.ac.uk/centaur}

\section{CentAUR}

Central Archive at the University of Reading

Reading's research outputs online 


\title{
Ruth Evans' book chapter for edited book, 'Intergenerational Space'
}

\section{Title: Negotiating intergenerational relations and care in diverse African contexts}

\begin{abstract}
:
Concerns about spaces of age segregation and generational separation in people's lives appear to reflect the interests of research and policy in the global North. In diverse contexts in Africa, the everyday lives of different generations are often integrated within families and communities, based on an implicit intergenerational contract (Collard, 2000; Kabeer, 2000) and generational hierarchies (Reynolds Whyte et al., 2008). This chapter draws on recent literature on youth transitions, generations in Africa (Alber et al., 2008; Christiansen et al., 2006; Punch, 2002) and empirical research on intergenerational caring relations in families affected by HIV in Tanzania and Uganda and among those who have experienced bereavement in Senegal. I explore how inter- and intra-generational relations and transitions to 'adulthood' may be changing in diverse African contexts. 'Homespace' and the 'community' are analysed as key sites where gendered, age-based and generational identities and power relations are reproduced, contested and negotiated. Reciprocal caring relations and responsibilities may strengthen emotional connections between members of different generations. Dominant gendered and generational norms may also become more fluid. While young people are often expected to care for family members and contribute to the household from an early age, however, they may also be regarded as a threat to the generational order (Diouf, 2003) when they engage in activities conventionally associated with adulthood, such as heading sibling households without a co-resident adult and young parenting outside of marriage. This may result in marginalisation and intergenerational tensions that impact on young people's wellbeing and future life transitions. To conclude, I reflect on how 'intergenerationality' contributes to geographies of care, family relations and life transitions.
\end{abstract}

\section{Contact details:}

Dr. Ruth Evans

Associate Professor in Human Geography

Department of Geography \& Environmental Science

University of Reading

Whiteknights PO Box 227

Reading RG6 6AB

UK

Email: r.evans@ @reading.ac.uk

Tel. 01183787755.

(C) Ruth Evans, February 2014. Please cite as: Evans, R. (in press) 'Negotiating intergenerational relations and care in diverse African contexts', in Vanderbeck, R. and Worth, N. (Eds).

Intergenerational Space, Routledge. 


\section{Negotiating intergenerational relations and care in diverse African contexts}

\section{Ruth Evans}

\section{Introduction: Intergenerational relations, ageing and development}

This chapter discusses how intergenerational relations and care may be changing in a range of African contexts. ${ }^{1}$ Following an overview of the connections between intergenerational relations, global population ageing and development, I discuss the theoretical concepts of 'generation' and the 'generational bargain'. Drawing on empirical research with families affected by HIV in Tanzania and Uganda and among those who have experienced bereavement in Senegal ${ }^{2}$, I explore everyday caring practices and intergenerational dynamics. The spaces of 'home' and the 'community' are analysed as key sites where gendered and agebased identities and generational power relations are reproduced, negotiated and contested. I also analyse how inter- and intra-generational caring relations shape young people's transitions to 'adulthood'. To conclude, I reflect on the contribution of 'intergenerationality' to geographies of care, family relations and life transitions.

Concerns about spaces of age segregation and generational separation in people's lives (Vanderbeck, 2007) appear to reflect the interests of research and policy in the global North. Yet, issues of population ageing and intergenerational relations are particularly pertinent to the global South. The older population of the world is increasing rapidly as a result of sustained gains in longevity and declines in fertility over the last century. While the highest proportions of older people (aged 60 and over) as a percentage of the population currently live in the global North, almost two thirds of the world's older population live in the global South $(54 \%$ live in Asia) (UN, 2009). Furthermore, the increase in the older population in the twenty-first century will be greatest and most rapid in the global South (Zelenev, 2008), where countries are already facing enormous challenges associated with economic restructuring, industrialisation, urbanisation, changing household and family structures, environmental degradation and climate change. Older people in the global South, especially older women, are often perceived as particularly vulnerable to poverty, ill health, disability and abuse. Formal safety nets and social protection mechanisms for older and young people are very limited and concern has been expressed that some countries 'will grow old before they grow rich' (Powell, 2010, p.3). Older people's active contributions to society, strong familial responsibilities towards older relatives and the respect older people often command within age hierarchies in many cultures and social institutions, however, reveal the dangers of constructing older people as a passive, homogeneous vulnerable group.

Despite this global context, development agencies and researchers have only recently started to investigate the connections between age, intergenerational relations and development in the global South. Reflecting the tendency noted in the global North to 'fetishise' the margins (the young and the old) and to overlook the 'middle generation' (Vanderbeck, 2007; Hopkins and Pain, 2007), research has tended to focus either on children and youth, or, to a lesser extent, older people in the global South.

\section{'Generations' in Africa}

In diverse contexts in Africa, the everyday lives of different generations are often integrated within families and communities, based on an implicit 'intergenerational contract' (Kabeer, 
2000; Collard, 2000) and generational hierarchies (Alber et al., 2008). In many African countries, there is a long history of child fosterage practices and household structures are complex and fluid (Young and Ansell, 2003; Notermans, 2008). From Senegal to South Africa, many families live in large, multi-generational households, especially in rural areas (Bass and Sow, 2006; Schatz and Ogunmefun, 2007). These may be headed by an older or middle-aged male 'patriarch' who is generally expected to provide shelter and financial support, while women are usually responsible for basic household needs, including domestic chores, food production and preparation and caring for children and sick or elderly relatives (Oheneba-Sakyi and Takyi, 2006). Men and women often have separate budgets, investments and different responsibilities for household expenditure, and wives, daughters and other female relatives may have considerable autonomy to earn their own income and to provide for their children. Children and young people in Africa have long been expected to contribute to the household from an early age, according to gendered and age-based norms of productive and social reproductive work (Evans, 2010). The family home is thus a crucial site where gendered and age-based identities and generational power relations are reproduced and contested (Evans, 2012a; in press).

Processes of urbanisation and economic crisis have led to a substantial increase in marital dissolution in many African countries in recent years, and growing numbers of women head or principally maintain households, particularly in urban areas (Oheneba-Sakyi and Takyi, 2006). There is also considerable mobility between rural and urban households and intrahousehold exchanges of resources. For example, family members of different generations move to live with relatives for temporary or longer periods to gain access to care, material resources, education, training and employment opportunities (Van Blerk and Ansell, 2006; Evans, 2005; Skovdal, 2011). Evidence from 21 African countries, including those with high and low HIV prevalence, suggests that there has been a shift towards grandparents taking an increased childcare responsibility in recent years, especially where orphan rates are growing rapidly (Beegle et al., 2010).

As Oheneba-Sakyi and Takyi (2006: 14) note, historically, the relationship between the generations in African societies has been based on 'the value of the knowledge, respect and experience that the younger generation receives from the older generation'. Indeed, these values and recognition of children's place within generational hierarchies are enshrined in the African Charter on the Rights and Welfare of the Child (1990). Article 31 - 'The

Responsibility of the Child', states that, among other duties, 'the child, subject to his (sic) age and ability, shall have the duty to work for the cohesion of the family, to respect his parents, superiors and elders at all times and to assist them in case of need'; and 'to preserve and strengthen African cultural values in his relations with other members of the society, in the spirit of tolerance, dialogue and consultation and to contribute to the moral well-being of society'.

Anthropological literature on generational relations and transitions between different life phases is useful in conceptualising notions of 'generation' and relatedness. Reynold Whyte et al. (2008: 4-6) identify three main understandings of 'generation'. The first, most common conceptualisation within African anthropology is as a genealogical relation of kinship, which refers to an individual's generational position within families, focusing on descent, filiation and succession. In classic studies of genealogical generations, conflict between generations

(C) Ruth Evans, February 2014. Please cite as: Evans, R. (in press) 'Negotiating intergenerational relations and care in diverse African contexts', in Vanderbeck, R. and Worth, N. (Eds).

Intergenerational Space, Routledge. 
over the allocation of resources and within a generation over rights to succeed to office and property were prominent themes. The second, overlapping understanding is of 'generation' as a principle for structuring society, beyond the specific links of kinship. This understanding is similar to age, but rather than referring to chronological age through the life course which usually corresponds to biological ageing, it refers to the ways that 'maturational age, life stages or age grades are socially marked and recognized as milestones or phases that do not always correspond to chronological age' (Reynolds Whyte et al. 2008, 4). It is thus a relational term that may denote social categories of seniors and juniors in society and which is often used alongside the terms 'age and 'life stage'. The third concept of generation is the idea of historical generation or generation as cohort which is often traced back to Karl Manheim's [1927] seminal essay 'The problem of generations'. Reynolds Whyte et al. (2006: 6) argue that analysis of historical generations shows how change occurs unevenly, since differences and conflicts are found both within generations and between them. Recent literature on youth in contemporary African societies has drawn on this understanding of generation to explore the historical circumstances of a particular cohort affected by economic crisis, urbanisation, migration, conflict, the HIV epidemic and other development challenges (Cruise O’Brien, 1996; Christiansen et al., 2006; Diouf, 2003).

Building on Reynolds Whyte et al's (2006) first and third understandings of 'generation', generational transfers and intergenerational caring relations in the global South have been theorised using the concept of a 'generational bargain' (Collard, 2000) and 'intergenerational contract' (Kabeer, 2000). The bargain is that the most economically active 'middle generation' makes transfers to the young with the expectation that resources will be reciprocated to them in old age when they require care and support, while also fulfilling their obligations to support their elderly parents. Collard (2000, p. 456) suggests that the generational bargain relies on each generation making 'such transfers as are consistent with each cohort having a good life-prospect', which can break down if the middle generation is unable to make the necessary transfer of resources to the young and old.

Research suggests that the 'generational bargain' is coming under increasing pressure in much of the global South due to societal transformations associated with a range of global processes. These include globalisation, neoliberal economic restructuring, the HIV epidemic and the consequences of reduced public health spending, user fees and policies that emphasise home-based care (Ogden et al., 2006), rapid urbanisation, high levels of transnational and rural-urban migration, greater emphasis on education, changing family structures and the individualisation of kinship responsibilities (Kabeer, 2000; Van Blerk and Ansell, 2007). Such changes affect the ability of the middle generation to provide care and support for younger and older generations in a range of familial contexts. The ways that intergenerational relations are changing in contemporary African societies are explored in more depth through a focus on the everyday socio-spatial and temporal contexts of caring relations in Tanzania, Uganda and Senegal.

\section{Changing inter- and intra-generational relations in homespace}

In Eastern and Southern Africa, three decades of the HIV epidemic have taken a considerable toll on the ability of families and communities to care for large numbers of people living with a chronic life-limiting illness, orphaned children and youth and older people whose adult children have died (Evans, 2010). The loss of the parental 'middle generation' has led to the

(C) Ruth Evans, February 2014. Please cite as: Evans, R. (in press) 'Negotiating intergenerational relations and care in diverse African contexts', in Vanderbeck, R. and Worth, N. (Eds).

Intergenerational Space, Routledge. 
emergence of new household forms, such as 'skipped generation households' (where the older generation live with orphaned children without any co-resident middle-aged adults) and 'child- and youth-headed households' (where siblings live independently without a coresident adult relative) (Samuels and Wells, 2009; Evans, 2011). In the context of stigma and changing kinship responsibilities, grandmothers play a crucial role in caring for widows living with HIV and children who have been orphaned by AIDS (Van Blerk and Ansell, 2007; Schatz and Ogunmefun, 2007; Nyambedha et al., 2009).

A growing literature has demonstrated the significance of children's roles in caring for chronically ill parents, younger siblings and other community members in HIV-affected communities in Eastern and Southern Africa (Bauman et al., 2006; Robson et al, 2006; Skovdal, 2011). Children's responsibilities to provide care for adults call into question conventional norms of generation and parenting. Adopting an ethic of care (Tronto, 1993) perspective, my research has shown, however, that care-giving is not a one-way process, but rather children, parents and other family members provide reciprocal care within the household (Evans and Becker, 2009; Evans and Thomas, 2009). Indeed, caring relations and responsibilities may strengthen emotional connections between members of different generations, which may help to protect 'care-givers' from negative outcomes. The reciprocity and mutual emotional support that characterised parent-child caring relations refutes negative assumptions about the competence of parents living with HIV to provide good care for their children and notions of 'parentification' (that caregiving children become their 'parent's parent') that have been discussed by some authors (Bauman et al, 2006; Oduaran and Oduaran, 2010).

Furthermore, mothers with HIV and grandparents maintained their position of moral authority in the household and were responsible for decision-making, the allocation of resources and providing emotional support, discipline and informal education for children, despite children's responsibilities for income-earning and domestic, health-related and personal care tasks (Evans, 2010). Unsurprisingly, adults continued to occupy positions of power and have higher social status than children, despite their illness and/or infirmity in old age. This highlights the methodological importance of researching the perspectives of both 'care-givers' and 'care-receivers' involved in intergenerational caring relations.

While care is shaped by wider gendered and generational power relations, dominant norms may also become more fluid within the home. For example, in Tanzania, almost as many boys provided care for their mothers/female relatives as the number of girls. Some boys provided personal care for their mothers, despite the fact that this subverted dominant gender norms and preferences for 'gender matching' between 'care-giver' and 'care-receiver' (Evans and Becker, 2009). Boys who took on caring roles that were considered to transgress culturally accepted gender boundaries, however, sometimes faced significant social consequences, such as bullying and ostracism within the community.

Anthropological literature has highlighted the cultural importance of older siblings' roles in caring for younger siblings and in socialisation and informal training in many African societies (LeVine et al, 1996). Very few geographical studies have focused on sibling relations to date (see Punch, 2001; Klett-Davies 2008 for notable exceptions). In the context of the HIV epidemic in Tanzania and Uganda, sibling relationships may be crucial in

(C) Ruth Evans, February 2014. Please cite as: Evans, R. (in press) 'Negotiating intergenerational relations and care in diverse African contexts', in Vanderbeck, R. and Worth, N. (Eds).

Intergenerational Space, Routledge. 
ensuring the survival of the sibling group and access to inherited assets following parental death (Evans, 2013; 2012b). Orphaned siblings heading child- and youth-headed households usually developed interdependent caring relations and shared domestic duties within the home (Evans, 2011). The household was reconfigured as a more autonomous space free of the usual intergenerational hierarchy. In contrast to previous negative experiences in foster relatives' households, young people were able to manage the household independently of adult control. In participatory workshops in Tanzania, siblings identified close relationships and freedom and autonomy to make decisions as positive aspects of living together, in addition to highlighting the poverty, lack of basic needs and loneliness they experienced.

It is important not to romanticise such intra-generational relations, however, since they are shaped by wider social norms and often reproduce hierarchies of gender, age and sibling birth order. Older siblings often sought to maintain such hierarchies in order to manage younger siblings' misbehaviour, which sometimes led to tensions and conflict. Young people also reproduced conventional gender norms in the allocation and negotiation of household chores and care work between siblings. Young women heading households reported spending more time each week doing domestic duties and managing the household, while young men heading households tended to share the care work and allocate household chores to younger siblings (particularly girls). Young men spent many more hours than young women each week engaging in paid work and other income-generation activities to support the family financially (Evans, 2012a). This was linked to gendered constructions of domestic duties and care, in addition to gendered inequalities in access to employment opportunities.

Many eldest siblings in Tanzania and Uganda perceived caring for their siblings in terms of taking on an adult role as the breadwinner and took pride in their role as head of the family. Hamisa (aged 19, Tanzania) said:

'Me? I see myself as an adult because I look after my young sister and I look after myself without depending on my mother, without saying that 'my mother will buy me clothes, will cook for me, I will ask her for a pen'. I know how to manage my finances as a father or mother'.

Young people also identified themselves as a parent/guardian for their younger siblings because of their role in providing moral guidance and teaching to their siblings, attempting to fulfil the parental role their mother or father would have performed if they were still alive, as research with child-headed households in Zambia also found (Bell and Payne, 2009). Some young men appeared to enjoy their 'adult' responsibilities in managing the household and commanding respect from their younger siblings. Rickson emphasised his authoritative role in the family:

'I see myself as a grown up person because I am the one leading the family. I have authority over my siblings'.

However, young people's accounts also highlighted the ambiguous position that they occupied as an elder sibling taking on a full-time parental caring role. Several young people expressed contradictory feelings about assuming 'adult' responsibilities whilst they still considered themselves a 'child'.

(C) Ruth Evans, February 2014. Please cite as: Evans, R. (in press) 'Negotiating intergenerational relations and care in diverse African contexts', in Vanderbeck, R. and Worth, N. (Eds).

Intergenerational Space, Routledge. 
As a West African country with a much lower prevalence of HIV, Senegal provides an interesting contrast to the East African context. My research with Serer family members of different generations who had experienced an adult relative's death in recent years in rural and urban Senegal reveals how a death may represent a 'vital conjuncture' (Johnson-Hanks, 2002) that reconfigures intergenerational caring relations and family practices within the home (Evans, in press). Young people saw their roles predominantly in terms of 'caring about' and 'taking care of' (Tronto, 1993) bereaved family members through assuming responsibility and providing financial support to meet their needs. However, many were also involved in practical 'care-giving' activities within the home, such as childcare, informal teaching and disciplining of younger siblings, undertaking domestic chores (young women only) and providing emotional support for a grieving parent and other family members. Young women also engaged in paid domestic work to earn an income to support their families or to pay for their school expenses during the school vacations. For 'double orphans', the death of both parents could result in a reconfiguration of kinship relations and a move to live with maternal relatives if paternal relatives were unwilling to accept their conventional responsibilities. This enabled family members to redefine kinship relations and to deemphasise some familial ties, revealing the fluid, contingent nature of kinship that is lived and re-made through shared family practices and intergenerational care (Morgan, 2011; Carsten, 2004).

Young people's involvement in caring for bereaved family members in Senegal was associated with agency (Tronto, 1993) and reaffirmed their position within the household, their sense of responsibility towards their younger siblings and their role in the intergenerational contract. In the context of very limited social protection to support children and older people in many African countries, older youth and adult offspring were expected to support their bereaved mother and siblings following the death of a male head of household. Several young people articulated a heightened awareness of the mortality of close, surviving family members and were committed to fulfilling their role in the intergenerational contract. Anna (aged 27), for example, had completed teacher training and was about to start her first teaching post at the time of the interview. She commented:

'[...] even if I have brothers and sisters who do so already, I must also support her. Beside my father, I was a child, but now, I have set myself a goal: to help my mother because she's the only one I have left, so I must do all I can for her'.

Following parental death, eldest sons living in rural areas in Senegal gained from intergenerational transfers of wealth, such as inherited land and livestock, and were able to re-assert their role within the household. This sometimes led to shifts in power relations and the fulfilment of the intergenerational contract, as the eldest son became the 'Kilifa', or head of the household and was regarded as the moral authority, responsible for decision-making over household expenses and providing for younger siblings, step-mothers and their children and other relatives. Young people's role in the intergenerational contract also influenced their ties to the family home and their future aspirations and life transitions. Samba (aged 27), whose mother had died, for example, wanted to do an apprenticeship in construction work with a relative in Dakar. He said that he would nevertheless return to the village during the rainy season to help his father with the agricultural work and then leave again for the city

(C) Ruth Evans, February 2014. Please cite as: Evans, R. (in press) 'Negotiating intergenerational relations and care in diverse African contexts', in Vanderbeck, R. and Worth, N. (Eds).

Intergenerational Space, Routledge. 
when the crops had been harvested. He anticipated marrying and bringing his future wife to live in the family home, since he would be the eventual heir, as he explained:

'If I marry, I will bring her here to live together with the family because the house belongs to me, I am there with my father and the children, so, this house belongs to me'.

A wife and children would enhance Samba's status within the household and eventually he would be expected to assume greater responsibility as head of the household, as his father aged and became less able to sustain the household through physically demanding farm work. This demonstrates how a parent's death and subsequent life transitions may reaffirm young people's role in the intergenerational contract and the family practices (Morgan, 2011) in which they engage.

\section{Changing intergenerational relations in 'community' spaces}

As Hopkins and Pain (2007: 289, italics in original) comment, an intergenerational perspective foregrounds the understanding that 'identities of children and others are produced through interactions with other age/generational groups and are in a constant state of flux'.

Although some young people in Tanzania and Uganda enjoyed their position of power within the household and were proud of their 'adult' responsibilities as the head of the family, young people often found that they had low social status within the community and were not treated as 'adults' in decision-making processes. Rickson (aged 19, Tanzania) felt that it was better to adopt the position of a child within the community:

'In the village, when it comes to participating in things, I don't get involved, I position myself as a child, a student who goes to school, I become young. I don't get involved with parents. I become like a child, although in our house, I become like parents, but when with others, I become young, like a young child'.

As Bushin et al. (2007: 76) note, 'young people construct their identities in part through the discourses that are available to them', including amongst others, 'ontological narratives (used by individual social actors to make sense of their lives)' and 'public narratives (used by institutions varying from family, workplace, church, government, nation)'. Rickson's selfidentification as a 'young child' in the village can be interpreted in the context of wider international, national and local discourses of orphanhood in Tanzania (and other SubSaharan African countries) that seek to identify the 'most vulnerable' children in need of support according to strict age criteria, levels of poverty and relations with adult caregivers (MHSW, 2008). In order to continue to access support and resources from NGOs and members of the community, young people, particularly those who exceed the usual ageboundaries of qualifying for support, may seek to emphasise their vulnerability as children lacking adult supervision rather than demonstrating their competencies as youth who were 'managing their own lives'. This reveals the ways that young people perform their 'social age' (Solberg, 1997) and demonstrate or disguise their competencies according to the potential benefits associated with appearing 'older' or 'younger'.

Global discourses of orphanhood co-existed alongside local constructions of young people's 'deviancy' based on the ways that sibling-headed households transgressed African socio-

(C) Ruth Evans, February 2014. Please cite as: Evans, R. (in press) 'Negotiating intergenerational relations and care in diverse African contexts', in Vanderbeck, R. and Worth, N. (Eds).

Intergenerational Space, Routledge. 
cultural norms of 'the family', kinship responsibilities and household formation. While many young people developed supportive relationships with neighbours, relatives, community leaders and others who they often turned to for advice, company and material support, several young people had direct experiences of stigmatisation linked to poverty, orphanhood and AIDS. Young people found themselves in a weak bargaining position to negotiate a fair payment for casual work, with people sometimes refusing to pay them for work they had completed. Young people in Uganda who had inherited property experienced difficulties securing rental income from tenants or found that relatives often took this money, leaving them with just a small amount of food instead. Several young people said that they were regularly insulted and intimidated by neighbours who, according to the young people, were trying to force them out of their home to seize their land.

Young people's narratives also reveal the strategies they adopted to resist marginalisation and harassment, such as seeking protection from community leaders and neighbours, developing supportive friendships with their peers and interdependence and solidarity between siblings, or suppressing their emotions and becoming highly self-reliant. Hamisa (aged 19, Tanzania) saw community leaders as a key source of protection:

'Some bad neighbours come at night and throw stones at my roof, so I'm too scared to sleep. But I went to our local leader and informed him about this, they started to guard us. So I don't have this problem anymore'.

This reveals the ambiguous nature of young people's agency (Robson et al., 2007) and 'place' within the community, as they are positioned and position themselves simultaneously as vulnerable dependents in need of protection and support from adults and as competent social actors able to manage their lives and to call on the resources of others.

\section{Changing transitions to 'adulthood'}

In many African countries (Ansell, 2004; Langevang, 2008), marriage continues to be considered the key marker of 'adulthood' for young men and women, particularly in rural areas. The research from Tanzania, Uganda and Senegal suggests, however, that marriage was not regarded as an immediate priority for most young people interviewed, despite its importance as a marker of adult status. Young people's caregiving roles for siblings and other family members represented a long term commitment which was sustained as young people grew older, in spite of such socially expected lifecourse transitions. Both young men and women heading households in Tanzania and Uganda regarded completing their educations and achieving a level of financial security as much higher priorities for themselves and their siblings than marriage. Young women in all three countries expressed concerns about being economically dependent on a husband. They instead articulated a strong desire to obtain a good job that enabled them to support themselves and their family before they considered marriage and motherhood.

However, the steps towards achieving 'successful adulthood' (Langevang, 2008) did not necessarily always happen in the order young people wished. Khady (aged 20, Senegal), for example, had a three year old daughter and was unmarried, but was able to return to school to complete her Baccalaureat. She hoped to marry the father of her child and obtain a job in nursing or teaching in future. The notion that young people posed a threat to the generational order (Diouf, 2003) was evident in assumptions and unease about the unregulated bodies and

(C) Ruth Evans, February 2014. Please cite as: Evans, R. (in press) 'Negotiating intergenerational relations and care in diverse African contexts', in Vanderbeck, R. and Worth, N. (Eds).

Intergenerational Space, Routledge. 
sexuality of young people, particularly young women, who had children outside of marriage and/or lived independently and headed households without 'adult' supervision. In Tanzania and Uganda, young women heading households and living alone with their siblings were considered to be particularly vulnerable to sexual abuse, coercion, pregnancy and/or early marriage. The stigma and sexual harassment they faced reveal public disquiet about their 'inbetween' place between adolescence and adulthood as 'not-quite adults' who were taking on 'adult' roles.

Some young people in Senegal articulated a desire to travel and migrate to Europe or the US if employment opportunities were available. As Hertrick and Lesclingand (2013) argue in relation to Mali, labour migration has increasingly become regarded as a key event in youth transitions to adulthood for both genders in the West African context. Mobility between urban centres within countries may also represent a key strategy for young people to develop the skills, social networks and access to employment opportunities needed to achieve future financial security (Langevang, 2008; Punch, 2002; Evans, 2012a). Young people's experiences in Tanzania and Uganda suggest, however, that sibling caregiving may prevent young people from taking up employment opportunities and pursuing migration strategies that would help to reduce their vulnerability to chronic poverty over the lifecourse (Evans, 2012a).

Although marriage and having the financial means to provide for a wife and children was strongly associated with 'successful adulthood' for young men in rural areas in Senegal, older youth who had only studied for a few years of primary school expressed a strong commitment to continue to support their younger siblings and other family members in future. Issa (aged 25) for example, had paid the bridewealth for his financée, but she had not yet joined the marital home. He explained that the marriage celebration would not take place until he had enough money the following year or longer if necessary. He emphasised that his responsibilities towards his widowed step-mother and younger siblings came first:

'Today, where I would like to be, I don't want to abandon them. I will always fulfil my duties towards them [...] If you do things which exceed your means, you are going to really rack your brains. I have to look after the daily needs of the home and other things and when you have responsibilities, you have to go step by step, go very gently'.

Hertrich and Lesclingand (2013) among others have argued that young men often delay marriage for financial reasons, leading to young people occupying the liminal category of 'youth' for increasingly prolonged periods (Cruise O'Brien, 1996; Christensen et al, 2006). My research suggests that both young men and women may also delay marriage and migration and may not take up educational or employment opportunities due to their interand intra-generational caring responsibilities.

\section{Conclusion}

Rather than becoming 'fractured', as some have argued (Collard, 2000; Van Blerk and Ansell, 2007), my research suggests that the 'generational bargain' continues to underpin intergenerational relations and familial caring responsibilities in East and West Africa. Nevertheless, the generational bargain is coming under increasing pressure in the context of

(C) Ruth Evans, February 2014. Please cite as: Evans, R. (in press) 'Negotiating intergenerational relations and care in diverse African contexts', in Vanderbeck, R. and Worth, N. (Eds).

Intergenerational Space, Routledge. 
rapid processes of economic and social change in many African countries, including economic restructuring, high levels of transnational and rural-urban migration and urbanisation (Hertrich and Lesclingand, 2013; UN Habitat, 2013), the global HIV epidemic and the policy emphasis on 'home-based care' (Ogden et al, 2006), limited formal safety nets and social protection for children, older people and persons living with disability and chronic illness (UNICEF, 2009) and an increasing individualisation of familial responsibilities (Kabeer, 2000; Evans and Becker, 2009). The loss of the 'middle generation' due to AIDSrelated and other deaths, in addition to these wider structural processes, mean that young people in contemporary African countries are called on to take responsibility, and provide care, for older generations at a much younger age than usual. Young people may have limited access to informal and formal support, in addition to less human capital (education, training and life and livelihood skills) to draw on than middle generational cohorts who supported the young and old in previous historical periods.

The examples from Tanzania, Uganda and Senegal reveal the dynamic, constantly shifting nature of the generational categories of 'childhood', 'youth' and 'adulthood', which are negotiated within specific temporal and spatial contexts. Young people affected by parental death may be regarded as a moral threat to the generational order (Diouf, 2003) when they engage in activities conventionally associated with adulthood, such as heading households without a co-resident adult relative or young parenting outside of marriage. This may result in marginalisation and intergenerational tensions that impact on young people's wellbeing and future life transitions (Evans, 2011; 2012a). It is important to note, however, that the death of a close adult relative is not necessarily always associated with biographical disruption and a reconfiguration of intergenerational caring relations; it may be associated with continuities in family practices, reaffirming young people's role in the intergenerational contract and leading to few, if any, changes in material circumstances or living arrangements (Evans, in press). Thus, while changes may be occurring in response to different pressures in many African countries, generational hierarchies, intergenerational caring relations and respect for elders are also enduring features of African societies.

This chapter has shown that 'intergenerationality' provides useful insights into the spaces and temporalities of care, family practices and lifecourse transitions. Geographers have much to contribute to analyses of how intergenerational caring relations may be changing across time and space. However, a focus on inter-generational geographies should not lead to the neglect of analyses of intra-generational relations, such as those between siblings and peers, which may be significant throughout the lifecourse (Punch, 2002; Evans, 2012a; in press; Skovdal and Onyango Ogutu, 2012). This reveals the importance of drawing on related concepts, such as the lifecourse and intersectionality, in developing future relational geographies of age (Hopkins and Pain, 2007).

\section{Notes}

1. This chapter synthesises some of the arguments made in Evans (2011;2012a; in press) and Chapter 4.5 'Ageing and Development' in Potter et al. (2012).

2. For research methods used in these studies, see Evans (2011; 2012a; in press). I am grateful to the Royal Geographical Society (with the IBG) and the University of Reading for funding these studies.

\section{References}

(C) Ruth Evans, February 2014. Please cite as: Evans, R. (in press) 'Negotiating intergenerational relations and care in diverse African contexts', in Vanderbeck, R. and Worth, N. (Eds).

Intergenerational Space, Routledge. 
Alber, E., Van de Geest, S. and Reynolds Whyte, S. (eds.) (2008) Generations in Africa. Berlin: Lit Verlag.

Ansell, N. (2004) 'Secondary schooling and rural youth transitions in Lesotho and Zimbabwe', Youth and Society, 36(2): 183-202.

Bass, L. and Sow, F. (2006) 'Senegalese families: the confluence of ethnicity, history and social change', in Y. Oheneba-Sakyi and B. Takyi (eds.), African Families at the Turn of the $21^{\text {st }}$ Century, Westport: Praeger, pp.83-102.

Bauman, L., Foster, G., Johnson Silver, E., Gamble, I. and Muchaneta, L. (2006) 'Children caring for their ill parents with HIV/AIDS', Vulnerable Children and Youth Studies, 1(1): 114.

Beegle, K., Filmer, D., Stokes, A. and Teirerova, L. (2010) 'Orphanhood and the living arrangements of children in sub-Saharan Africa', World Development, 38(2): 1727-1746.

Bell, S. and Payne, R. (2009) 'Young people as agents in development processes: reconsidering perspectives for development geography', Third World Quarterly, 30(5): 1027-1044.

Bushin, N., Ansell, N., Adriansen, H., Lähteenmaa, J., and Panelli, R. (2007) 'Reflecting on contexts and identities for young rural lives', in R. Panelli, S. Punch and E. Robson (eds.) Global Perspectives on Rural Childhood and Youth: Youth Rural Lives, London: Routledge: 69-80.

Carsten, J. (2004) After Kinship, Cambridge: Cambridge University Press.

Christiansen, C., Utas, M., Vigh, H. (2006) 'Youth(e)scapes', in C. Christiansen, M. Utas and H. Vigh (eds.) Navigating Youth Generating Adulthood: Social Becoming in an African Context, Stockholm: Nordiska Afrikainstitutet.

Collard, D. (2000) 'Generational Transfers and the Generational Bargain', Journal of International Development, 12: 453-462.

Cruise O'Brien, D. (1996) 'A lost generation? Youth identity and state decay in West Africa', in R. Werbner and T. Ranger (eds.) Postcolonial Identities in Africa, London: Zed Books. Diouf, M. (2003) 'Engaging postcolonial cultures: African youth and public space', African Studies Review, 46 (2): 1-12.

Evans, R. (in press) 'Parental death as a vital conjuncture? Intergenerational care and responsibility following bereavement in Senegal', Social and Cultural Geography.

Evans, R. (2013) 'Young people's caring relations and transitions within families affected by HIV', in J. Ribbens McCarthy, C. Hooper and V. Gillies (eds), Family Troubles? Exploring changes and challenges in the family lives of children and young people, Bristol: The Policy Press, pp.233-243.

Evans, R. (2012a) 'Sibling caringscapes: time-space practices of caring within youth-headed households in Tanzania and Uganda', Geoforum, 43: 824-835.

Evans, R. (2012b) 'Safeguarding inherited assets and enhancing the resilience of young people living in child- and youth-headed households in Tanzania and Uganda', African Journal of AIDS Research, 11(3): 177-189.

Evans, R. (2011) "We are managing our own lives...": Life transitions and care in siblingheaded households affected by AIDS in Tanzania and Uganda', Area, 43 (4): 384-396. Evans R. (2010) Children's caring roles and responsibilities within the family in Africa, Geography Compass, 4 (10): 1477-1496

(C) Ruth Evans, February 2014. Please cite as: Evans, R. (in press) 'Negotiating intergenerational relations and care in diverse African contexts', in Vanderbeck, R. and Worth, N. (Eds).

Intergenerational Space, Routledge. 
Evans, R. and Thomas, F. (2009) 'Emotional interactions and an ethic of care: caring relations in families affected by HIV and AIDS', Emotions, Space and Society, 2: 111-119.

Evans, R. and Becker, S., (2009) Children Caring for Parents with HIV and AIDS: Global Issues and Policy Responses, Bristol: The Policy Press.

Evans, R. (2005) 'Social networks, migration and care in Tanzania: caregivers' and children's resilience in coping with HIV/ AIDS', Journal of Children and Poverty, 11: 111-29.

Hertrich, V. and Lesclingand, M. (2013) 'Adolescent migration in rural Africa as a challenge to gender and intergenerational relationships: evidence from Mali', Annals of the American Academy, 648: 175-188.

Hopkins, P. and Pain, R. (2007) 'Geographies of age: thinking relationally', Area, 39(3): 287294.

Kabeer, N. (2000) 'Inter-generational contracts, demographic transitions and the "quantityquality" trade-off: parents, children and investing in the future', Journal of International Development, 12(4): 463-482.

Klett-Davies, M. (ed.) (2008) Putting Sibling Relationships on the Map: A Multidisciplinary Perspective, London: Family and Parenting Institute.

Langevang, T. (2008) "We are managing!" Uncertain paths to respectable adulthoods in Accra Ghana', Geoforum, 39: 2039-2047.

LeVine, R., Dixon, S., LeVine, S., Richman, A., Leiderman, P., Keefer, C., Brazelton, T., (1996) Child Care and Culture: Lessons from Africa, New York: Cambridge University Press.

Lloyd-Sherlock, P. (2004) 'Ageing, development and social protection: generalisations, myths and stereotypes' in P. Lloyd-Sherlock (ed.) Living Longer: Ageing, Development and Social Protection, London: Zed Books, pp.1-17.

Morgan, D. (2011) Rethinking Family Practices. Palgrave MacMillan, Basingstoke.

MHSW (Ministry of Health and Social Welfare) 2008 The National Costed Plan of Action for Most Vulnerable Children 2007-2010 Department of Social Welfare MHSW United Republic of Tanzania

Notermans, C. (2008) 'The emotional world of kinship. Children's experiences of fosterage in East Cameroon', Childhood, 15(3): 355-377.

Nyambedha, E., Wandibba, S., Aagaard-Hansen, J., (2003) 'Changing patterns of orphan care due to the HIV epidemic in Western Kenya', Social Science and Medicine, 57: 301-11.

Oduaran, A and Oduaran, C. (2010) 'Grandparents and HIV and AIDS in Sub-Saharan Africa', in M. Izuhara (ed.) Ageing and Intergenerational Relations. Family Reciprocity from a Global Perspective, Bristol: The Policy Press, pp. 95-110.

Ogden, J., Esim, S. and Grown, C. (2006) 'Expanding the care continuum for HIV/AIDS:

bringing carers into focus', Health Policy and Planning, 21(5): 333-342.

Oheneba-Sakyi, Y and Takyi, B. (2006) 'Introduction to the study of African families: a framework for analysis', in Y. Oheneba-Sakyi and B. Takyi (eds.), African Families at the Turn of the $21^{\text {st }}$ Century, Westport: Praeger, pp.1-23.

Potter, R., Conway, D., Evans, R. and Lloyd-Evans, S. (2012) Key Concepts in Development Geography, Sage: London

Powell, J. (2010) 'The power of global aging', Ageing International, 35: 1-14.

Punch, S. (2002) 'Youth transitions and interdependent adult-child relations in rural Bolivia', Journal of Rural Studies, 18: 123-133

Punch, S. (2001) 'Household division of labour: generation, gender, age, birth order and sibling composition', Work, Employment and Society, 15(4): 803-23.

(C) Ruth Evans, February 2014. Please cite as: Evans, R. (in press) 'Negotiating intergenerational relations and care in diverse African contexts', in Vanderbeck, R. and Worth, N. (Eds).

Intergenerational Space, Routledge. 
Reynolds Whyte, S., Alber, E. and van de Geest, S. (2008) 'Generational connections and conflicts in Africa: an introduction', in E. Alber, S. Van de Geest and S. Reynolds Whyte (eds.) (2008) Generations in Africa, Berlin: Lit Verlag, pp.1-23.

Robson, E., Ansell, N., Huber, U. S., Gould, W. T. S., van Blerk, L. (2006) 'Young caregivers in the context of the HIV/AIDS pandemic in sub-Saharan Africa', Population, Space and Place, 12: 93-111.

Robson, E., Bell, S. and Klocker, N. (2007) 'Conceptualising agency in the lives and actions of rural young people', in R. Panelli, S. Punch and E. Robson (eds.) Global Perspectives on Rural Childhood and Youth: Youth Rural Lives, London: Routledge, pp.135-148.

Samuels, F. and Wells, J. (2009) 'The loss of the middle ground: the impact of crises and HIV and AIDS on "skipped-generation" households', ODI Project Briefing No. 33, London: Overseas Development Institute.

Skovdal, M. (2011) 'Examining the trajectories of children providing care for adults in rural Kenya: implications for service delivery', Children and Youth Services Review, 33: 12621269.

Skovdal, M. and Onyango Ogutu, V. (2012) 'Coping with hardship through friendship: the importance of peer social capital among children affected by HIV in Kenya', African Journal of AIDS Research, 11(3): 241-250.

Tronto, J. (1993) Moral Boundaries. A Political Argument for an Ethic of Care. New York and London: Routledge.

UNICEF (2009) La Protection Sociale des Enfants en Afrique de l'Ouest et du Centre. Etude de cas du Sénégal. UNICEF.

UN (2009) Population Ageing and Development 2009, Department of Economic and Social Affairs, United Nations Population Division, www.unpopulation.org (accessed 16/05/11). United Nations Human Settlements Programme (2013) State of the World's Cities 2012/2013, Nairobi: UN-Habitat.

Vanderbeck, R. (2007) 'Intergenerational geographies: age relations, segregation and reengagements', Geography Compass, 1(2): 200-221.

Van Blerk, L. and Ansell, N. (2007) 'Alternative strategies for care giving in the context of AIDS in Southern Africa: complex strategies for care', Journal of International Development, 19: 865-84.

Van Blerk, L. and Ansell, N. (2006) 'Children's experiences of migration: moving in the wake of AIDS in southern Africa', Environment and Planning D: Society and Space, 24: 449471.

Young, L. and Ansell, N. (2003) 'Fluid Households, Complex Families: The Impacts of Children's Migration as a Response to HIV/AIDS in Southern Africa', The Professional Geographer, 55(4): 464-476.

Zelenev, S. (2008) 'The Madrid Plan: a Comprehensive Agenda for an Ageing World' in Review Report 2008 of The Madrid International Plan of Action on Ageing, United Nations: New York, pp. 1-17, ww.un.org (accessed 16/05/11)

(C) Ruth Evans, February 2014. Please cite as: Evans, R. (in press) 'Negotiating intergenerational relations and care in diverse African contexts', in Vanderbeck, R. and Worth, N. (Eds).

Intergenerational Space, Routledge. 